\title{
Development of a sperm cryopreservation protocol of Gangetic Mystus
}

\section{(Mystus cavasius)}

\author{
MM Islam ${ }^{*}$, MN Noor ${ }^{2}$, AA Islam², MRI Sarder², MZ Islam², DA Jahan ${ }^{3}$ \\ ${ }^{1}$ Department of Fish Biology and Biotechnology, Chittagong Veterinary and Animal Sciences University, Khulshi, \\ Chittagong 4225, Bangladesh; ${ }^{2}$ Department of Fisheries Biology and Genetics, Bangladesh Agricultural University, \\ Mymensingh 2202, Bangladesh; ${ }^{3}$ Bangladesh Fisheries Research Institute, Mymensing 2202, Bangladesh
}

\begin{abstract}
Cryopreservation is considered as one of the most useful techniques for long-term preservation of genetic material specially sperm of fish. This study focused on the development of a sperm cryopreservation protocol for indigenous near threatened gulsha (Mystus cavasius) and a number of experiments were conducted for the purpose. To collect milt, male gulsha were sacrificed and milt was suspended in extenders. Different concentrations of $\mathrm{NaCl}$ were used to evaluate the activation of sperm motility and it decreased as the concentration of the extending media increased, therefore, motility was completely inhibited at $0.8 \%$ and $1.2 \% \mathrm{NaCl}$ solution when sperm suspended in Kurokura-2 and Alsever's solution, respectively. The toxicity of cryoprotectants to sperm were evaluated using two cryoprotectants, dimethyl sulfoxide (DMSO) and methanol along with the extenders, Alsever's solution and Kurokura-2 solution. DMSO and methanol with $5 \%$ and $10 \%$ concentrations produced significantly higher motility during 5 and 10 min incubation and their $15 \%$ concentration found toxic to sperm. Alsever's solution with $10 \%$ DMSO produced best equilibration $(83.75 \pm 2.39 \%)$ as well as post-thaw motility $(67.5 \pm 3.23 \%)$ while Kurokura-2 solution with DMSO produced similar equilibration motility $(81.25 \pm 2.39 \%)$ but the post-thaw motility $(50.0 \pm 6.12 \%)$ was significantly much lower than that of Alsever's solution. Sperm preserved with Alsever's solution plus DMSO produced highest fertilization, $72.5 \pm 7.5 \%$ and hatching, $56.8 \pm 5.6 \%$ while fresh sperm yielded $85.0 \pm 5.0 \%$ and $74.8 \pm 3.6 \%$ fertilization and hatching, respectively. The protocols that have been developed can be used for conservation of genetic materials of $M$. cavasius and other endangered fish species and new generations of them can be propagated using the cryopreserved sperm.
\end{abstract}

Key words: Mystus cavasius, Sperm, Cryopreservation, Breeding, Conservation

Progressive Agriculturists. All rights reserve

*Corresponding Author: moududislam@gmail.com

\section{Introduction}

Bangladesh endowed with diversified aquatic resources having approximately 300 freshwater and brackish water fish species (DoF, 2015). Unfortunately, abundances of many fish species have been declined and some of them become endangered due to overfishing, application of pesticides, aquatic pollution, stocking of exotic fishes, habitat degradation, excessive use of water in irrigation and siltation. According to (IUCN, 2015) there are as many as 91 species are considered as threatened and near threatened and among them gulsha is categorized as near threatened species. So, immediate measures need to be taken for 
their ex situ (cryopreservation of sperm) and in situ (captive rearing) conservation.

Mystus cavasius (Hamilton,1822) is a freshwater catfish under the family Bagridae of order Siluriformes and commonly known as Gangetic Mystus. It is a delicious food fish of Indian subcontinent and demands high market price. M. cavasius is widely distributed in Bangladesh and some other Asian countries, Myanmar and Thailand (Talwar and Jhingran, 1991). They are found in flooded canals, beels, paddy and jute fields, haors, baors, ponds and rivers in rainy season (Bhuiyan, 1964; Shafi and Quddus, 1982). It is worthy to mention here that the genetic diversity of the species is being reduced with the decrease of abundance. As a result the gene pool of $M$. cavasius is narrowed down and they are exposed to the threat of extinction.

It is, therefore, important to take immediate measures to conserve the genetic resources of the species and to do so an integrated approach, for example, live gene banking (domestication and reared in ponds) and cryogenic gene banking can be taken. Cryopreservation is a technique for long-term preservation and storage of biological materials at very low temperature, usually at $-196^{\circ} \mathrm{C}$. This low temperature ensures the cellular viability with genetically stable form in storage condition (Ashwood-Smith, 1980). Cryopreservation is an effective way to preserve genetic materials of important fish species and as a whole to conserve the biodiversity. Cryopreservation protocols have been developed for more than 200 finfish and shellfish species in the world (Tiersch, 2000). Cryopreservation of sperm of the tropical bagrid catfish (Mystus nemurus) was done where the effects of extender and cryoprotectant on sperm motility were determined (Muchlisin et al., 2004). Similarly, Linhart et al. (2005) cryopreserved sperm of European catfish (Silurus glanis). Viveiros et al. (2000) developed the cryopreservation protocols for sperm of African catfish (Clarias gariepinus) and they optimized the sperm: egg ratio for artificial breeding. Viveiros et al. (2001) also investigated the optimum cooling rate of sperm of
African catfish (Clarias gariepinus) and temperature falling at -5 to $-10^{\circ} \mathrm{C} / \mathrm{min}$ was found most suitable. Protocols for cryopreservation of sperm of endangered Ompok pabda (Sarder et al., 2013); Nandus nandus (Sarder et al., 2012) and minor carps, Olive barb (Nahiduzzaman et al., 2011) have been developed in Bangladesh. Though M. cavasius is becoming endangered, it has not been a subject to cryopreservation anywhere in the world. So, development of sperm cryopreservation protocols of gulsha would assist to conserve the existing genetic resource of the species and ensure supply of sperm for propagating new generation. However, the specific objectives of the study were designed to assess the quality of sperm; toxicity level of cryoprotectants to sperm; suitability of selective diluents and efficacy of cryopreserved sperm in artificial breeding.

\section{Materials and Methods}

\section{Experimental fish collection and rearing}

Matured M. cavasius were collected from natural sources (rivers, haors) and stocked in ponds and cisterns of Faculty of Fisheries, Bangladesh Agricultural University (BAU), Mymensingh, Bangladesh and Bangladesh Fisheries Research Institute, Mymensingh. A commercial supplemental feed named Mega feed containing about 35\% protein was provided two times a day at $4-5 \%$ of total body weight of fish. To increase the natural food production of the pond, organic (cow dung) and inorganic (urea and phosphate) fertilizers were also applied at a rate of $2.0 \mathrm{~kg} /$ decimal and $150 \mathrm{~g} /$ decimal respectively, at 15 days interval. Liming (250 g/decimal/month) was also done to ensure the quality of water.

\section{Selection and conditioning of brood fish}

Matured males were selected on the basis of desired phenotypic characteristics. They were caught from the pond 4-6 h prior to hormone treatment and kept in cistern for conditioning. During conditioning, no feed was supplied to them. Additional aeration was ensured 
by continuous supply of water through PVC pipe over the cistern.

\section{Sperm collection, quality assessment and its counting}

For sperm collection male brood fish, 6-12 g in body weight were transferred from the rearing pond to the cistern of the mini-hatchery and induced with pituitary gland (PG) hormone. Male broods were induced with a single dose of PG extract of $2 \mathrm{mg} / \mathrm{kg}$ body weight. After hormone injection the fish were kept in cistern for about $7 \mathrm{~h}$ and the testes were collected by dissection as milt cannot be collected through stripping. The testes were weighed and put in a watch glass placed on ice. As the milt was viscous, a small amount of extender solution (Alsever's solution and Kurokura-2 solution) was added to the testes separately and crushed them gently using a scissor so that the sperm is suspended in the extender. The chemical constituents of two extenders were different but preparation process was same (Table 1).

Table 1. Chemical constituents and preparation protocol of different extenders used for cryopreservation of sperm of $M$. cavasius.

\begin{tabular}{|l|c|c|}
\hline $\begin{array}{l}\text { Extender } \\
\text { constituent }\end{array}$ & $\begin{array}{l}\text { Alsever's } \\
\text { solution }\end{array}$ & Kurokura-2 solution \\
\hline Sodium chloride & $0.4 \%$ & $0.36 \%$ \\
Sodium citrate & $0.8 \%$ & - \\
Calcium chloride & - & $0.022 \%$ \\
Potassium chloride & - & $1 \%$ \\
Magnesium & - & $0.008 \%$ \\
chloride & - & $0.02 \%$ \\
Sodium hydrogen & Dissolved in 100 & Dissolved in $100 \mathrm{ml}$ of \\
carbonate & ml of distilled & distilled water \\
& water & \\
\hline
\end{tabular}

The sperm suspension was collected using a micropipette and kept in an eppendorf. The eppendorf was placed on ice. Since the quality of sperm can be varied between samples, its motility was observed under a light binocular microscope. To standardize milt dilution and also to estimate the density of sperm per straw, the concentration of milt was determined by counting the sperm using a haemocytometer. The concentration of fresh sperm ranged from $9.65 \times 10^{9}$ to $1.09 \times 10^{10}$ cells $/ \mathrm{ml}$.

\section{Estimation of sperm motility}

About 1- $2 \mu 1$ sperm suspension was put on a glass slide, and $80-100 \mu l$ of distilled water was mixed to the suspension to activate the sperm. Immediately after activation the motility of sperm was examined under a compound microscope. The sperm which had active movement were counted and expressed as percent motility. For each milt sample, the estimation of sperm motility was done for at least three times in five fields observed each time.

\section{Collection of eggs for fertilization}

Matured females, 20-40g in body weight, were caught from the stocking ponds and transferred to the cistern $\left(216 \times 182 \times 54 \mathrm{~cm}\right.$; water temperature, $\left.26-28^{\circ} \mathrm{C}\right)$ for acclimatization for at least $6 \mathrm{~h}$ before they were induced with PG extract. Two PG hormone injections were administered at $6 \mathrm{~h}$ interval with the doses of 6 $\mathrm{mg} / \mathrm{kg}$ and $12 \mathrm{mg} / \mathrm{kg}$ body weight for the first and second injection respectively. The hormone-injected brood fish were retained in the cistern for ovulation which takes $6-8 \mathrm{~h}$.

\section{Experiment-I: Activation of sperm at various concentrations of $\mathrm{NaCl}$}

Activation of sperm motility was performed at different concentrations of $\mathrm{NaCl}$ solution (Sarder et al., 2012). After maceration of testes collected sperm was suspended in extender and placed on ice. A good number of male fish were sacrificed for each extending medium. Twelve graded dilutions of $\mathrm{NaCl}$ solution (from $0.1 \%$ to $1.2 \%$ ) were prepared by dissolving $\mathrm{NaCl}$ with distilled water. For activation of the sperm 1-2 $\mu 1$ of sperm suspension was taken on a glass slide and 20 $\mu \mathrm{l}$ of $\mathrm{NaCl}$ solution from each of the graded dilutions was added to it. Then sperm motility in each of the dilution was examined under microscope. The motility (percentage) and swimming duration (second) of 
activated sperm at different concentrations of $\mathrm{NaCl}$ solution were recorded. These parameters were determined by calculating time difference from activation to the completely immotile or near to immotile condition of the sperm.

\section{Experiment-II: Evaluation of toxicity effect of cryoprotectant to sperm}

The toxicity effect of cryoprotectant to sperm was assessed following the method described by Sarder et al. (2012). Two extenders, Alsever's solution and Kurokura-2 solution and two cryoprotectants, DMSO and methanol were used. Milt was collected following the methods described above and diluted at 1:9 (milt:diluent) for both Alsever's solution and Kurokura-2 solution. The dilution ratio between milt and diluent was selected from the studies of Indian Major Carp Catla catla (Kumar 1988, 1989; Sarder et al., 2009), Common Carp Cyprinus carpio (Magyary et al., 2000), and Silver Carp Hypophthalmichthys molitrix (Hossain and Sarder, 2009). The cryoprotectants (DMSO, methanol) were mixed with the milt in such a way that the final concentration of the cryprotectants would be settled at 5, 10 and $15 \%$. The mixtures were placed on ice. The toxicity of these cryoprotectants was assessed by monitoring the motility of sperm under a microscope for a maximum of $60 \mathrm{~min}$ incubation period with $5 \mathrm{~min}$ interval.

\section{Experiment-III: Selection of suitable diluents (extender+cryoprotectant)}

For selecting suitable extenders and cryoprotectants, two extenders such as Alsever's solution and Kurokura-2 solution and two cryoprotectants, DMSO and methanol were used. The chemical constituents of different extenders are presented in Table 1.To prepare the standard diluent (extender + cryoprotectant) $10 \%$ cryoprotectant was added to $90 \%$ extender $(\% \mathrm{v} / \mathrm{v})$. After mixing sperm with the diluent, 8-10 min were left for equilibration of the sperm. During equilibration $0.23 \mathrm{ml}$ diluted milt was drawn into each $0.25 \mathrm{ml}$ plastic French straws (Minitüb System, Minitüb, Tiefenbach, Germany) by a micro-pipette. The free ends of the straws were manually sealed with the help of a heated crucible tongs. The motility of sperm in all the samples was examined beforeaddition of cryoprotectant and again just before initiation of freezing as equilibration motility.

\section{Freezing and thawing of milt}

Straws those contained diluted milt were loaded into the cryochamber of a computer controlled-rate freezer (CL 3300) (Cryologic, Pty Ltd., Australia 1998 \& 1999) for freezing. The freezing rate was optimized through several trials. A one-step freezing protocol was used where milt samples were cooled from $0^{\circ} \mathrm{C}$ to $-80^{\circ} \mathrm{C}$ at the temperature falling rate of $10^{\circ} \mathrm{C} / \mathrm{min}$. After freezing, the samples were transferred into liquid nitrogen $\left(-196^{\circ} \mathrm{C}\right)$ for storage. For observing the postthaw motility of sperm frozen straws were retrieved from the $\mathrm{LN}_{2}$ container using a tweezer and thawed at room temperature for $30-40 \mathrm{~s}$. One to $2 \mu \mathrm{l}$ of thawed milt was taken onto a glass slide and 150-200 $\mu$ l of distilled water was added to activate the sperm. The motility of sperm was assessed under a binocular microscope.

\section{Experiment IV: Effects of cryopreservation on fertilization and hatching of eggs}

Freshly collected eggs were fertilized with cryopreserved sperm and fresh sperm. Mature females were induced with PG extract and eggs were stripped into a plastic bowl from the ovulated females. The collected egg mass was divided into batches depending on number of eggs (approximately 500 eggs in each batch) and treatments (sperm preserved with different diluents) for fertilization. Four batches of eggs were fertilized with sperm preserved with two different diluents and each diluent had two replications. Two batches of eggs were fertilized with fresh sperm as control. After thawing at room temperature for about $30-40$ s, the straws were cut at both ends and sperm was mixed with eggs. For fertilization, each batch of eggs was mixed with $6 \times 230 \mu$ l of cryopreserved milt 
where each straw contained $230 \mu \mathrm{l}$ milt. The eggs and sperm were mixed gently using a clean hen feather and some tap water was added during mixing. The fertilized eggs were transferred into incubation tray and continuous water shower was provided over the tray to ensure additional dissolved oxygen. To observe the progress of cell division of eggs of both cryopreserved and control groups, eggs were taken under microscope after 1 hour of fertilization. The fertilized eggs look vivid and transparent while unfertilized eggs look turbid and possess white chorion. After 16 to $24 \mathrm{~h}$ of fertilization hatching of eggs took place. The hatchlings of each group were counted and transferred to plastic bowls for rearing. The fertilization and hatching rates of eggs were calculated by the following formulae respectively:

$\frac{\text { No.of fertilized eggs }}{\text { Total number of eggs }} \times 100$ and

No. of hatched eggs

Total number of eggs $\times 100$

\section{Statistical analysis}

Motility of sperm in experiments I, II, III were presented as percentage and all percent motility values were subjected to arcsine transformation before analysis. Data of experiments I and II were analyzed using Independent -samples T test of SPSS v 16 and the means were separated by Least Significant Difference (LSD) at 5\% level of significance. To analyze the effects of different extenders and cryoprotectants and their combinations (Expt. III) on both equilibration and post-thaw motility of sperm, one way ANOVA of SPSS (version 16) was used. Means were separated by Duncan's Multiple Range Test (DMRT) at 5\% level of significance. For breeding trial (Expt. IV), Independent-samples T- test of SPSS (version 16) was applied to compare the performance of sperm preserved with different diluents.

\section{Results}

\section{Activation of sperm motility at various concentrations of $\mathrm{NaCl}$}

The activation of sperm motility varied with different concentration of salt solution ( $\% \mathrm{NaCl}$ solution) and the sperm motility decreased with the increase of $\mathrm{NaCl}$ concentration. About $80-90 \%$ forward movement and $10-20 \%$ Brownian movement were recorded from the sperm samples preserved with different solutions. In presence of Alsever's solution the motility of sperm was recorded as $92.5 \pm 2.5 \%$ at $0.1 \% \mathrm{NaCl}$ which decreased to $77.5 \pm 2.5 \%$ at $0.4 \% \mathrm{NaCl}$ solution. After that the motility has been sharply dropped as the concentration of $\mathrm{NaCl}$ increased and it was reflected with zero motility at $1.2 \% \mathrm{NaCl}$ solution (Figure 1). Sperm suspended in Kurokura-2 showed $90.0 \pm 0 \%$ motility at $0.1 \% \mathrm{NaCl}$ which increased to $92.5 \pm 2.5$ at $0.4 \% \mathrm{NaCl}$ solution. Then the motility sharply reduced and became zero at $0.8 \% \mathrm{NaCl}$ (Figure 2).

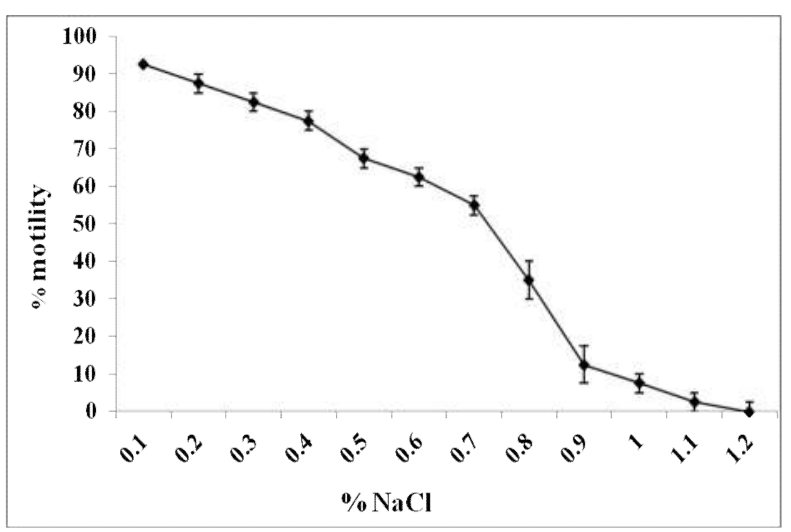

Figure 1. Motility of sperm of $M$. cavasius in different concentrations of $\mathrm{NaCl}$ solution $(0.1$ to $1.2 \%)$. Sperm was suspended in Alsever's solution during collection.

Motility of sperm was stable at $0.4 \% \mathrm{NaCl}$ for both Alsever's and Kurokura-2 solution and it was considered as complete activation. On the other hand, motility was completely inhibited at $1.2 \% \mathrm{NaCl}$ and $0.8 \% \mathrm{NaCl}$ for Alsever's solution and Kurokura-2 solution respectively. The statistical analysis revealed a 
significant difference $(P=0.003)$ between the complete activation and inhibition, i.e. 0.4 and $1.2 \% \mathrm{NaCl}$ for Alsever's solution and 0.4 and $0.8 \% \mathrm{NaCl}$ for Kurokura -2 solution respectively.

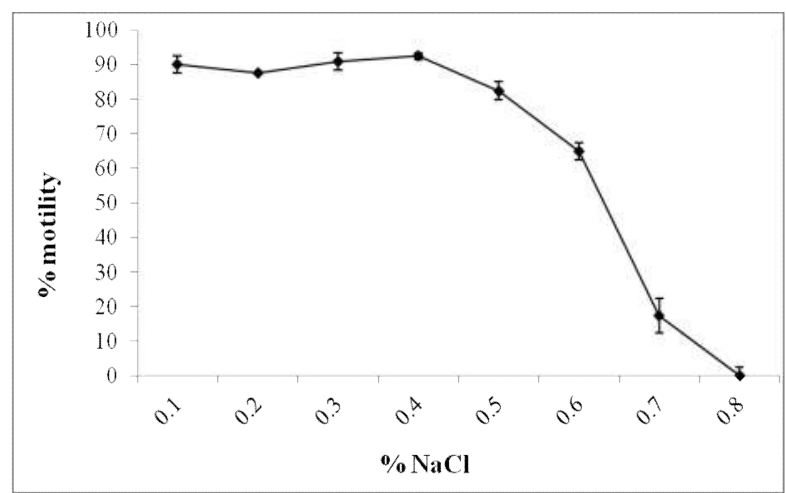

Figure 2. Motility of sperm of $M$. cavasius in different concentrations of $\mathrm{NaCl}$ solution (0.1 to $0.8 \%$ ). Sperm was suspended in Kurokura-2 solution during collection.

Swimming duration of sperm at various $\mathrm{NaCl}$ concentrations

The swimming duration of activated sperm varied with different $\mathrm{NaCl}$ concentrations and the duration was severely restricted with the increase of $\mathrm{NaCl}$ concentration. The duration of motility of sperm those were suspended in Alsever's solution was estimated as long as $11.63 \pm 3.4 \mathrm{~min}$ at $0.1 \% \mathrm{NaCl}$ and $21.45 \pm 3.0$ min at $0.2 \% \mathrm{NaCl}$ which was highest. Then swimming activity was fastly reduced with the increase of $\mathrm{NaCl}$ concentration and it became zero at $1.2 \% \mathrm{NaCl}$ (Figure 3). Similarly, sperm suspended in Kurokura-2 solution demonstrated its motility for $11.8 \pm 0 \mathrm{~min}$ at $0.1 \% \mathrm{NaCl}$ and $15.30 \pm 2.50 \mathrm{~min}$ at $0.2 \% \mathrm{NaCl}$ as highest (Figure 4). The swimming activity became zero at $0.8 \% \mathrm{NaCl}$. There was a significant difference between maximum swimming duration and complete inhibition of sperm those suspended in Alsever's solution $(P=0.018)$ and Kurokura-2 solution $(P=0.041)$.

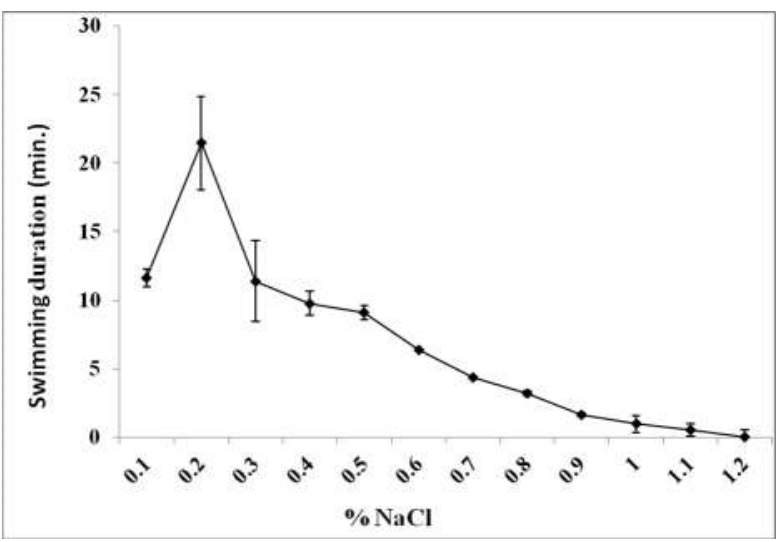

Figure 3. The swimming duration of sperm of $M$. cavasius in different concentrations of $\mathrm{NaCl}$ solution $(0.1$ to $1.2 \%)$. Sperm was suspended in Alsever's solution during collection.

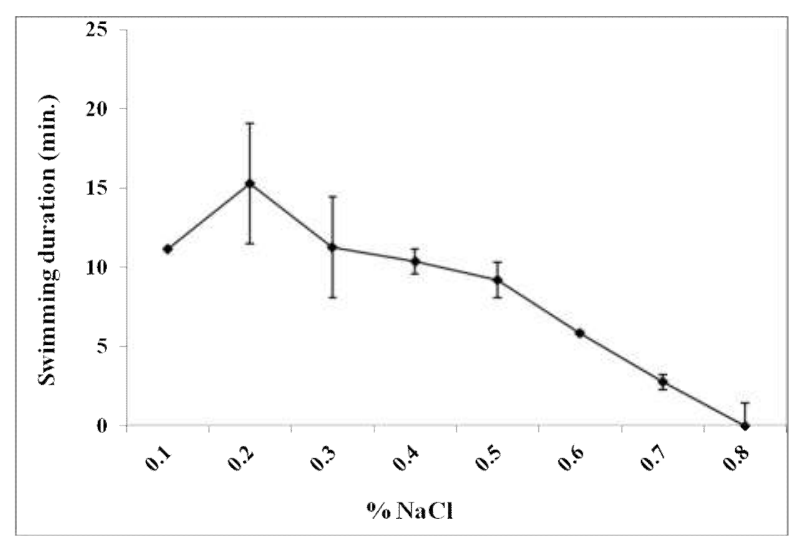

Figure 4. The swimming duration of sperm of $M$. cavasius in different concentrations of $\mathrm{NaCl}$ solution $(0.1$ to $0.8 \%)$. Sperm was suspended in Kurokura-2 solution during collection.

\section{Toxicity estimation of cryoprotectant to sperm}

Before incubation with the cryoprotectants DMSO and methanol fresh sperm of $M$. cavasius demonstrated 85$95 \%$ motility. However, the motility of sperm gradually decreased with the increase of cryoprotectant concentration (5, 10 and 15\%) and incubation time (5$60 \mathrm{~min})$. Along with Alsever's solution 5\% DMSO produced $62.5 \pm 2.5 \%$ motility at $5 \mathrm{~min}$ incubation 
which reduced to $52.5 \pm 2.5 \%$ at $10 \mathrm{~min}$ incubation $10 \%$ DMSO produced $72.5 \pm 2.5 \%$ motility at $5 \mathrm{~min}$ incubation and $65 \pm 5.0 \%$ at $10 \mathrm{~min}$ incubation (Table $2)$. No significant difference $(P=0.163)$ was observed between $5 \%$ and $10 \%$ of cryoprotectants during $10 \mathrm{~min}$ incubation.

In presence of Kurokura-2 solution, 5\% DMSO produced $85.0 \pm 0$ motility at $5 \mathrm{~min}$ incubation which reduced to $80.0 \pm 0$ at $10 \mathrm{~min}$. At $10 \%$ concentration DMSO produced $87.0 \pm 0 \%$ motility during $5 \mathrm{~min}$ exposure which reduced to $82.5 \pm 2.5 \%$ at $10 \mathrm{~min}$. DMSO at $15 \%$ concentration produced poor results from the beginning of incubation (Table 2). No significant difference $(P=0.423)$ was observed between $5 \%$ and $10 \%$ cryoprotectants during 10 min incubation. When methanol was used comparatively poor results were obtained from both Alsever's solution and kurokura-2 solution. Methanol with Alsever's solution at $5 \%$ concentration showed $45.0 \pm 0 \%$ motility at 10 min of incubation, where $10 \%$ methanol produced $40.0 \pm 5 \%$ motility at the same incubation time. Along with Kurokura-2, 5\% and 10\% methanol produced $72.5 \pm 2.5 \%$ and $77.5 \pm 2.5 \%$ motility at $10 \mathrm{~min}$ incubation respectively. Methanol at $15 \%$ concentration produced poor results with both Alsever's and Kurokura-2 solution (Table 2) and a significant difference $(P=0.042)$ was found at this concentration with Alsever's solution. Though 5\% and $10 \%$ cryoprotectants were less toxic to sperm, $10 \%$ cryoprotectant was applied in the subsequent experiments.

\section{Selection of suitable diluents}

The suitability of the extenders and cryoprotectants was assessed on the basis of sperm motility at equilibration and post-thaw period. The equilibration motility of sperm scored highest from Alsever's solution with DMSO $(83.8 \pm 2.4 \%)$ while $81.35 \pm 2.4 \%$ equilibration motility was recorded from Kurokura-2 solution. Highest post-thaw motility $(67.5 \pm 3.23 \%)$ was also observed from Alsever's solution with DMSO Both Alsever's and Kurokura-2 solution along with methanol produced very poor equilibration and postthaw motility and thus it was excluded from the fertilization trials (Figure 5). Statistical analysis showed that different combinations of diluents had significant effects on equilibration and post-thaw motility of sperm. A significant variation $(P=0.000)$ was found between two diluents, Alsever's solution plus DMSO and Alsever's solution plus methanol for both equilibration and post-thaw motility. On the other hand, Kurokura-2 solution with DMSO and methanol produced similar results. When the means of diluents were compared through Duncan's Multiple Range Test, it predicted that Alsever's solution plus DMSO to be the best combination for preservation of $M$. cavasius sperm.

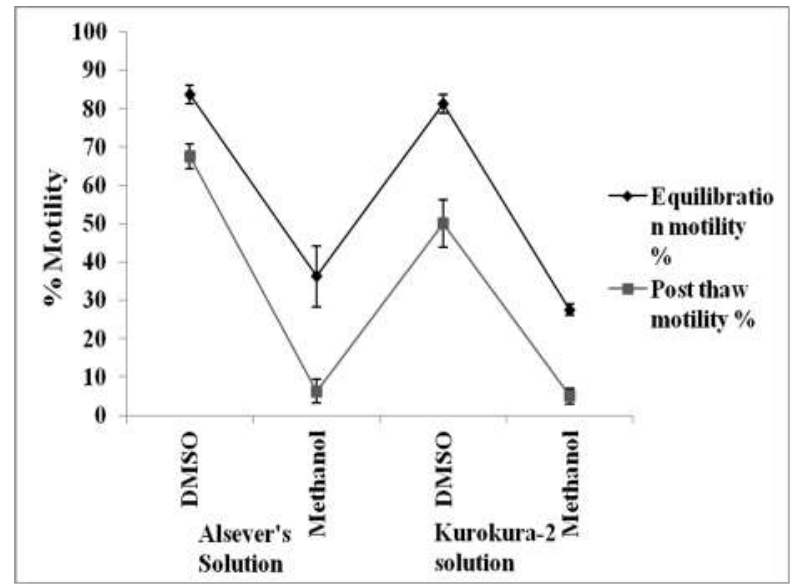

Figure 5. Equilibration and post-thaw motility of sperm of $M$. cavasius at different combinations of extender and cryoprotectant.

Fertilization and hatching of eggs with cryopreserved sperm

Eggs of M. cavasius were fertilized with both cryopreserved sperm and fresh sperm. For cryopreserved sperm two diluents Alsever's solution plus DMSO and Kurokura-2 solution plus DMSO were used. The post-thaw motility of sperm preserved with Alsever's solution plus DMSO was $67.5 \pm 3.2 \%$ and that was $50.0 \pm 6.12 \%$ for Kurokura-2 solution plus DMSO 
during fertilization of eggs. The highest fertilization, $72.5 \pm 7.5 \%$ and hatching, $56.8 \pm 5.6 \%$, was recorded from sperm preserved with Alsever's solution plus DMSO and those preserved with Kurokura-2 solution plus DMSO produced $67.5 \pm 2.5 \%$ and $38.2 \pm 13.0 \%$ fertilization and hatching respectively. Fresh sperm used as control yielded $85.0 \pm 5.0 \%$ and $74.8 \pm 3.6 \%$ fertilization and hatching respectively (Figure 6).

Table 2. Motility of M. cavasius sperm at different concentrations of cryoprotectants and incubation times using the extenders: Alsever's solution, and Kurokura-2. Data are presented as mean $\pm \mathrm{SE}$.

\begin{tabular}{|c|c|c|c|c|c|c|c|c|c|c|c|c|c|c|c|}
\hline \multirow{4}{*}{$\frac{\overrightarrow{0}}{\bar{E}}$} & \multirow{4}{*}{\multicolumn{2}{|c|}{$\begin{array}{c}\text { Cryo- } \\
\text { protectant }\end{array}$}} & \multicolumn{13}{|c|}{ Time (Min.) } \\
\hline & & & Initial & 5 & 10 & 15 & 20 & 25 & 30 & 35 & 40 & 45 & 50 & 55 & 60 \\
\hline & & & \multicolumn{13}{|c|}{ \% Motility } \\
\hline & & & Mean & Mean & Mean & Mean & Mean & Mean & Mean & Mean & Mean & Mean & Mean & Mean & Mean \\
\hline \multirow{6}{*}{ 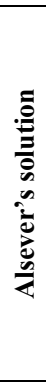 } & \multirow{3}{*}{ 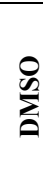 } & $5 \%$ & $\begin{array}{l}75.0 \\
\pm 0.0\end{array}$ & $\begin{array}{l}62.5 \\
\pm 2.5\end{array}$ & $\begin{array}{l}52.5 \\
\pm 2.5\end{array}$ & $\begin{array}{c}40.0 \\
\pm 0\end{array}$ & $\begin{array}{c}30.0 \\
\pm 5\end{array}$ & $\begin{array}{l}25.0 \\
\pm 5.0\end{array}$ & $\begin{array}{l}17.5 \\
\pm 2.5\end{array}$ & $\begin{array}{c}7.5 \\
\pm 2.5\end{array}$ & $\begin{array}{c}2.5 \\
\pm 2.5\end{array}$ & 0 & & & \\
\hline & & $10 \%$ & $\begin{array}{l}85.0 \\
\pm 0.0\end{array}$ & $\begin{array}{l}72.5 \\
\pm 2.5\end{array}$ & $\begin{array}{l}65.0 \\
\pm 5.0\end{array}$ & $\begin{array}{l}60.0 \\
\pm 5.0\end{array}$ & $\begin{array}{l}52.5 \\
\pm 7.5\end{array}$ & $\begin{array}{l}42.5 \\
\pm 7.5\end{array}$ & $\begin{array}{l}32.5 \\
\pm 7.5\end{array}$ & $\begin{array}{l}27.5 \\
\pm 7.5\end{array}$ & $\begin{array}{l}22.5 \\
\pm 7.5\end{array}$ & $\begin{array}{r}17.5 \\
\pm 7.5\end{array}$ & $\begin{array}{c}14.0 \\
\pm 6.0\end{array}$ & $\begin{array}{r}10.0 \\
\pm 5.0\end{array}$ & $\begin{array}{c}5.0 \\
\pm 5.0\end{array}$ \\
\hline & & $15 \%$ & $\begin{array}{l}75.0 \\
\pm 0.0\end{array}$ & $\begin{array}{l}62.5 \\
\pm 2.5\end{array}$ & $\begin{array}{l}52.5 \\
\pm 2.5\end{array}$ & $\begin{array}{l}42.5 \\
\pm 2.5\end{array}$ & $\begin{array}{l}32.5 \\
\pm 2.5\end{array}$ & $\begin{array}{l}22.5 \\
\pm 2.5\end{array}$ & $\begin{array}{l}17.5 \\
\pm 2.5\end{array}$ & $\begin{array}{l}12.5 \\
\pm 2.5\end{array}$ & $\begin{array}{c}6.5 \\
\pm 1.5\end{array}$ & $\begin{array}{c}2.5 \\
\pm 2.5\end{array}$ & 0 & & \\
\hline & \multirow{3}{*}{ 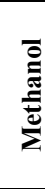 } & $5 \%$ & $\begin{array}{l}62.5 \\
\pm 2.5\end{array}$ & $\begin{array}{l}50.0 \\
\pm 5.0\end{array}$ & $\begin{array}{l}45.0 \\
\pm 5.0\end{array}$ & $\begin{array}{l}35.0 \\
\pm 5.0\end{array}$ & $\begin{array}{l}20.0 \\
\pm 5.0\end{array}$ & $\begin{array}{r}11.5 \\
\pm 3.5\end{array}$ & $\begin{array}{l}10.0 \\
\pm 5.0\end{array}$ & $\begin{array}{c}5.0 \\
\pm 5.0\end{array}$ & $\begin{array}{c}1.5 \\
\pm 1.5\end{array}$ & 0 & & & \\
\hline & & $10 \%$ & $\begin{array}{l}52.5 \\
\pm 2.5\end{array}$ & $\begin{array}{l}45.0 \\
\pm 5.0\end{array}$ & $\begin{array}{l}40.0 \\
\pm 5.0\end{array}$ & $\begin{array}{l}30.0 \\
\pm 5.0\end{array}$ & $\begin{array}{l}25.0 \\
\pm 5.0\end{array}$ & $\begin{array}{l}17.5 \\
\pm 2.5\end{array}$ & $\begin{array}{r}11.5 \\
\pm 3.5\end{array}$ & $\begin{array}{c}6.5 \\
\pm 3.5\end{array}$ & $\begin{array}{c}2.5 \\
\pm 2.5\end{array}$ & 0 & & & \\
\hline & & $15 \%$ & $\begin{array}{l}42.5 \\
\pm 2.5\end{array}$ & $\begin{array}{l}22.5 \\
\pm 2.5\end{array}$ & $\begin{array}{r}17.5 \\
\pm 2.5\end{array}$ & $\begin{array}{l}10.0 \\
\pm 0.0\end{array}$ & $\begin{array}{c}6.5 \\
\pm 1.5\end{array}$ & $\begin{array}{c}4.0 \\
\pm 1.0\end{array}$ & 0 & & & & & & \\
\hline \multirow{9}{*}{ 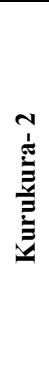 } & \multirow{4}{*}{$\sum_{0}^{0}$} & $5 \%$ & $\begin{array}{l}90.0 \\
\pm 0.0\end{array}$ & $\begin{array}{l}85.0 \\
\pm 0.0\end{array}$ & $\begin{array}{c}80.0 \\
\pm 0\end{array}$ & $\begin{array}{l}77.5 \\
\pm 2.5\end{array}$ & $\begin{array}{l}72.5 \\
\pm 2.5\end{array}$ & $\begin{array}{r}67.5 \\
\pm 2.5\end{array}$ & $\begin{array}{l}65.0 \\
\pm 5.0\end{array}$ & $\begin{array}{l}62.5 \\
\pm 2.5\end{array}$ & $\begin{array}{l}57.5 \\
\pm 2.5\end{array}$ & $\begin{array}{l}52.5 \\
\pm 2.5\end{array}$ & $\begin{array}{l}47.5 \\
\pm 2.5\end{array}$ & $\begin{array}{c}40.0 \\
\pm 0\end{array}$ & $\begin{array}{l}32.5 \\
\pm 2.5\end{array}$ \\
\hline & & $10 \%$ & 87.5 & 87.5 & 82.5 & 82.5 & 80.0 & 77.5 & 72.5 & 70.0 & 67.5 & 65.0 & 62.5 & 60.0 & 57.5 \\
\hline & & & \pm 2.5 & \pm 2.5 & \pm 2.5 & \pm 2.5 & \pm 5.0 & \pm 2.5 & \pm 2.5 & \pm 0 & \pm 2.5 & \pm 0 & \pm 2.5 & \pm 0 & \pm 2.5 \\
\hline & & $15 \%$ & $\begin{array}{l}80.0 \\
\pm 5.0\end{array}$ & $\begin{array}{l}72.5 \\
\pm 2.5\end{array}$ & $\begin{array}{l}67.0 \\
\pm 2.5\end{array}$ & $\begin{array}{l}65.0 \\
\pm 5.0\end{array}$ & $\begin{array}{l}55.0 \\
\pm 5.0\end{array}$ & $\begin{array}{l}45.0 \\
\pm 5.0\end{array}$ & $\begin{array}{l}35.0 \\
\pm 5.0\end{array}$ & $\begin{array}{l}27.5 \\
\pm 7.5\end{array}$ & $\begin{array}{l}20.0 \\
\pm 5.0\end{array}$ & $\begin{array}{l}11.5 \\
\pm 3.5\end{array}$ & $\begin{array}{c}7.5 \\
\pm 2.5\end{array}$ & $\begin{array}{c}5.0 \\
\pm 5.0\end{array}$ & $\begin{array}{c}2.5 \\
\pm 2.5\end{array}$ \\
\hline & \multirow{5}{*}{ 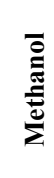 } & $5 \%$ & 82.5 & 77.5 & 72.5 & 70.0 & 65.0 & 60.0 & 52.5 & 47.5 & 42.5 & 40.0 & 35.0 & 27.5 & 22.5 \\
\hline & & & \pm 2.5 & \pm 2.5 & \pm 2.5 & \pm 5.0 & \pm 5.0 & \pm 5.0 & \pm 7.5 & \pm 7.5 & \pm 7.5 & \pm 5.0 & \pm 5 & \pm 2.5 & \pm 2.5 \\
\hline & & $10 \%$ & 82.5 & 80.0 & 77.5 & 75.0 & 72.5 & 67.5 & 67.5 & 62.5 & 62.5 & 57.5 & 57.5 & 50.0 & 47.5 \\
\hline & & & \pm 2.5 & \pm 5.0 & \pm 2.5 & \pm 5.0 & \pm 2.5 & \pm 2.5 & \pm 2.5 & \pm 2.5 & \pm 2.5 & \pm 2.5 & \pm 2.5 & \pm 0 & \pm 2.5 \\
\hline & & $15 \%$ & $\begin{array}{r}77.5 \\
+25\end{array}$ & $\begin{array}{r}72.5 \\
+25\end{array}$ & $\begin{array}{r}65.0 \\
+50\end{array}$ & $\begin{array}{r}57.5 \\
+25\end{array}$ & $\begin{array}{r}57.5 \\
+25\end{array}$ & $\begin{array}{r}47.5 \\
+25\end{array}$ & $\begin{array}{l}37.5 \\
+25\end{array}$ & $\begin{array}{r}32.5 \\
+25\end{array}$ & $\begin{array}{l}17.5 \\
+25\end{array}$ & $\begin{array}{r}9.0 \\
+10\end{array}$ & $\begin{array}{r}4.0 \\
+10\end{array}$ & 0 & \\
\hline
\end{tabular}

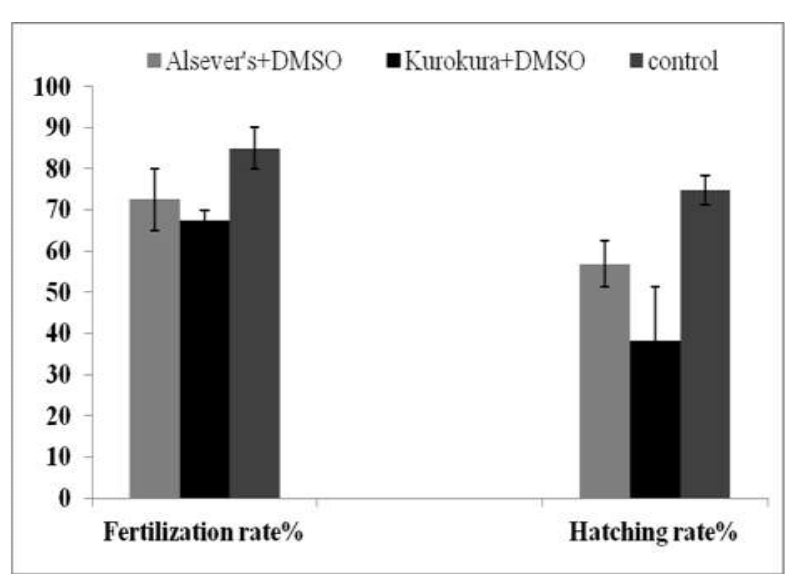

Figure 6. Fertilization and hatching of eggs of $M$. cavasius using cryopreserved and fresh sperm.
The breeding efficacy of cryopreserved sperm for two diluents was compared and a significant $(P<0.05)$ difference was found for hatching but not for fertilization $(P=0.592)$. Since the concentration of fresh and cryopreserved sperm was not standardized before fertilization, statistical comparison between the breeding performances of fresh and cryopreserved sperm was not possible.

\section{Discussion}

Formulation of suitable activation solution is very important for successful cryopreservation. The extenders are buffer like-solutions that may contain organic or inorganic chemicals and create an artificial medium for survival of the spermatozoa in liquid $\mathrm{N}_{2}$ ($\left.196^{\circ} \mathrm{C}\right)$ through providing the same osmotic pressure 
that it gets in fresh condition. Usually fish sperm remain immotile in the testis, and motility is regulated by different factors like osmolality of testicular fluid, ions, temperature, and $\mathrm{pH}$. However, among the factors osmolality plays the major role in sperm motility in most species. Generally, motility of sperm of freshwater fish species initiates in contract with hypotonic solutions while sperm of marine fish get motility in hypertonic solutions (Cosson 2004; Yang et al. 2006). In the present study the motility of sperm was assessed at different osmotic pressures using a graded series of $\% \mathrm{NaCl}$ solution and found that sperm motility decreased with increasing salt concentration. Sarder et al. (2012 \& 2013) reported that the activation of sperm motility decreased with the increase of the osmotic pressure of activation solution. The motility of sperm of the species was about $90 \%$ in $0.1 \% \mathrm{NaCl}$ solution which became zero at $1.1 \% \mathrm{NaCl}$ solution, i.e. the osmolality of seminal plasma was around 319 $\mathrm{mOsmol} / \mathrm{kg}$. It was reported that the osmolalities of seminal plasma of most freshwater cyprinids are between 230-346 mOsmol/kg (Alavi and Cosson, 2005).

Fish sperm start swimming after activation and it may continue for seconds to few minutes. When the sperm of $M$. cavasius was suspended in Alsever's and Kurokura-2 solutions, it demonstrated active movement in both extender solutions. At lower osmolalities the swimming activity of sperm existed for a longer period (about 15-20 mins), which gradually reduced as the concentration of the extending media increased. The motility of sperm severely reduced at $1.2 \% \mathrm{NaCl}$ with Alsever's solution and at $0.8 \% \mathrm{NaCl}$ with Kurokura-2 solution. However, in case of Zebra fish a reverse situation has been reported, where swimming activity of sperm was found to be extended in higher osmolalities (Yang et al., 2007). The duration of sperm motility varies among species and can be influenced by osmolality, temperature and $\mathrm{pH}$ (Alavi and Cosson, 2005; Alavi and Cosson, 2006).
Cryoprotectant is added to extender to minimize the stress on cells during cooling and freezing and also protect the cells from cold-shock during freezing. In spite of being toxic to cell, cryoprotectant is essential for cryopreservation of sperm. Permeability of cryoprotectants to cells differs and its concentration regulates the toxicity tolerance level of cells. So, concentration of cryoprotectant needs to be optimized. In the present study cryoprotectant was used at $10 \%$ $(\mathrm{v} / \mathrm{v})$ by volume as it has been commonly used for many species (Withler and Lim, 1982; Shirohara et al., 1982; Chao et al., 1975). The choice of the cryoprotectants was made following the studies of Yang et al. (2007) on Zebra fish and Sarder et al. (2012 and 2013) on Ompok pabda and Nandus nandus fish. Two cryoprotectants such as DMSO and methanol were used with different concentrations and the sperm suspension was incubated with them for 5 to $60 \mathrm{~min}$. In most of the cases, a better motility was observed during 5 and 10 min incubation at 5 and $10 \%$ concentrations of cryoprotectants but 15\% concentration appeared toxic and showed poor motility. At 5\% concentration, cryoprotectants produced better motility than $10 \%$ in many cases and it was supported by Leung (1987) who observed the best post-thaw motility of barramundi sperm at 5\% DMSO. DMSO, methanol, ethanol and DMA produced best post-thaw motility at their $10 \%$ concentration during cryopreservation of common carp (Cyprinus carpio) sperm (Sarder et al., 2009). Similar results with $10 \%$ concentration were reported from many species by Withler and Lim (1982); Shirohara et al. (1982) and Chao et al. (1975). Incubation of Olive barb (Puntius sarana) sperm with 5\% DMSO and methanol showed longer motility and 15\% concentration seemed toxic to sperm (Nahiduzzaman et al., 2011). DMSO and methanol at 5 and $10 \%$ concentrations produced better motility of sperm of Ompok pabda and Nandus nandus during 5 and $10 \mathrm{~min}$ incubation but $15 \%$ was toxic to sperm (Sarder et al., 2012 and 2013).

Selection of extender and cryoprotcetant is the prerequisite for the successful cryopreservation protocols. 
In this study, Alsever's solution and Kurokura-2 solution were applied with DMSO and methanol, and the dilution ratio between milt and diluent was maintained 1:9 for both the extenders.

Between the two cryoprotectants used, 10\% DMSO with Alsever's solution gave significantly better result compared to other combinations of extender and cryoprotectant at the post-thaw level. Alsever's solution with DMSO provided the highest equilibration and post-thaw motility of sperm which proved its suitability for cryopreservation of sperm of the species. It also indicates that Alsever's solution contains the osmotic pressure similar to that of sperm. Kumar (1989) reported that Alsever's solution had an excellent performance in cryopreservation of sperm of Indian major carp. Similar performance of Alsever's solution with10\% DMSO was also reported by Alvarez et al. (2003) during cryopreservation of sperm of silver carp (H. molitrix). Between the two cryoprotectants, DMSO performed best in producing equilibration and postthaw motility and it is not surprising as DMSO is considered an excellent cryoprotectant for cryopreservation of fish sperm (Lahnsteiner et al., 2000 and Billard et al., 2004) and cell lines (Zhang and Rawson, 2007). Rao (1989) argued that DMSO along with Alsever's solution might play a positive role in preservation by easily penetrating into the cellular membrane and bringing a balance between the intra and extra-cellular fluid concentrations (Ciereszko et al., 1993). In contrast, methanol yielded comparatively poor post-thaw motility; however, it was suitable for cryopreservation of sperm of zebra fish (Yang et al., 2007) and Olive barb (Nahiduzzaman et al., 2011).

Fertilization and hatching of eggs using cryopreserved sperm is the final target of developing cryopreservation protocol. The efficacy of the cryopreserved sperm to fertilize the egg is a key indicator in evaluating the success of cryopreservation (Honeyfield and Krise, 2000) and fertility of the frozen-thawed sperm is strongly positively correlated with its motility (Magyary et al., 1996). In the present study breeding trials were conducted using cryopreserved sperm preserved with two different diluents (Alsever's solution + DMSO and kurokura-2 solution + DMSO) but highest hatching rate was obtained from Alsever's solution plus DMSO. Fertilization and hatching of eggs by cryopreserved sperm have been possible but the results were inconsistent between trials. Variation of fertilization and hatching in subsequent breeding trials was reported by Rana and McAndrew (1989) where fertilization rates ranged from 38.7 to $93.4 \%$ of control after 13 months of storage of tilapia spermatozoa. Variation in fertilization and hatching of eggs of Ompok pabda and Nandus nandus using cryopreserved sperm was also reported by Sarder et al. (2012 and 2013).

To ensure the treatment effects fertilization of eggs with fresh sperm as control is most important and it helps to compare the outputs of various studies (Dong et al., 2007). However, since the number of sperm between fresh and cryopreserved was not standardized before fertilization in this study, no comparison for fertilization and hatching rates of eggs was made between them. Though fertilization rates with fresh sperm (>85\%) and cryopreserved sperm (70-90\%) approved the quality of eggs, the hatching rate was not satisfactory. The results suggested that the quality of cryopreserved sperm was good enough for fertilization but poor hatching may be caused due to faulty thawing technique of frozen sperm or any unidentified error in fertilization process. Therefore, to improve the fertilization and hatching rates of eggs special care should be taken during freezing and thawing of sperm in order to reduce the probable causes of cryoinjuries and damage in sperm.

\section{Conclusion}

Considering the threatened state and consumer choice of M. cavasius, it is utmost necessary to take immediate measures to protect their disappearance from natural water bodies. To our knowledge, this is the first attempt of cryopreservation of sperm of the fish as a conservation approach; it will help to conserve 
the existing gene pool of this endangered species. Though the cryopreservation protocol has been developed by this experiment, the fertilization and hatching rates of eggs should be improved before disseminate the techniques to hatchery operators. In addition, for sustainable use of sperm suitable egg sperm ratio and feasibility of cryogenic gene banking should be investigated.

\section{Conflict of interests}

The authors declare that they have no conflict of interests. The authors alone are responsible for the content and writing of the paper.

\section{Acknowledgements}

The authors would like to acknowledge the financial support of Infrastructural Development and Research Strengthening of the Bangladesh Fisheries Research Institute (IDRSBFRI) project for conducting the research

\section{References}

Alavi SMH, Cosson J (2006). Sperm motility in fishes-II. Effects of ions and osmolality: a review. Cell Biology International 30:1-14.

Alavi SMH, Cosson J (2005). Sperm motility in fishes. I. Effects of temperature and $\mathrm{pH}$ : a review. Cell Biol. Int., 29: 101-110.

Alvarez B, Fuentes R, Pimentel R, Abad Z, Cabrera E, Pimentel E, Arenal A (2003). High fry production rates using post-thaw silver carp (Hypophthalmichthus molitrix) spermatozoa under farming conditions. Aquaculture, 220: 195201.

Ashwood-Smith MJ, (1980). Low temperature preservation of cells, tissues, and organs.In: M. J. Ashwood-Smith and J. Farrant, (editors). Low temperature preservation in medicine and biology. Pittman Medical, Tunbridge Wells, Kent, UK.19-44 pp.

Bhuiyan AL (1964). Fishes of Dhaka. Asiatic Society of Pakistan, Dhaka, 148p.
Billard R, Cosson J, Noveiri SB, Pourkazemi M (2004). Cryopreservation and short-term storage of sturgeon sperm. Aquaculture, 236: 1-9.

Chao N, Chen HP, Chiuliao I (1975). Study on cryogenic preservation of grey mullet sperm. Aquaculture, 5: 389-406.

Ciereszko A, Ramseyer L, Dabrowski K (1993). Cryopreservation of yellow perch semen, Prog. Fish Cult.,55: 261-264.

Cosson J (2004). The ionic and osmotic factors controlling motility of fish spermatozoa Aquaculture International 12:69-85.

DOF (2015). Fish Week Compendium 2015. Department of Fisheries, Ministry of Fisheries and Livestock, Government of People's Republic of Bangladesh.134p.

Dong Q, Huang C, Tiersch TR (2007). Control of sperm solution is necessary for standardization of sperm cryopreservation in aquatic species: evidence from sperm agglutination in oysters. Cryobiology, 54: 87-98.

Honeyfield DC, Krise WF (2000). Measurement of milt quality and factors affecting viability of fish spermatozoa. In:Tiersch, T.R. and P.M. Mazik (eds.), Cryopreservation in Aquatic species, World Aquaculture Society, Baton Rouge, Louisiana, USA. 49-58 pp.

Hossain MS, Sarder MRI (2009). Cryogenic freezing of silver carp spermatozoa for conservation of gene pool. Progressive Agriculture, 20 (1\&2): 99106.

IUCN Bangladesh (2015). Red List of Bangladesh: A Brief on Assessment Result 2015. IUCN, International Union for Conservation of Nature, Bangladesh Country Office, Dhaka, Bangladesh.

Kumar K (1988). A comparative study of various extenders for cryopreservation of carp sepermatozoa. Indian Anim. Sci., 58(11): 13551360.

Kumar K (1989). Studies on cryogenic preservation of carp spermatozoa In: Das and Jhingran (eds.) 
Fish Genetics in India, Today and Tomorrows Printers and Publishers, New Delhi. pp.199-206.

Lahnsteiner F, Berger B, Horvath A, Urbanyi B, Weismann $T$ (2000). Cryopreservation of spermatozoa in cyprinid fishes. Theriogenology, 54: 1477-1498.

Leung LKP (1987). Cryopreservaton of spermatozoa of the barramundi, Latescalcarifer(Teleostei: Centropomidae). Aquaculture, 64: 243-247.

Linhart O, Rodina M, Flajshans M, Gela D, Kocour M. (2005). Cryopreservation of European catfish Silurus glanis sperm: sperm motility, viability, and hatching success of embryos. Cryobiology, 51: 250-261.

Magyary I, Dinnyes A, Urbanyi B (2000). Cryopreservation methods for sperm of the common carp. In: cryopreservation in Aquatic species. Tiersch, T.R. and P. M. Mazik (Editors).World Aquaculture society, Baton Roige, Louisiana.288-289 pp.

Magyary I, Urbanyi B, Horvath L (1996). Cryopreservation of common carp (Cyprinuscarpio L.) sperm: II. Optimal conditions for fertilization. J. Appl. Ichthyol., 12: 117-119.

Muchlisin ZA., Hashim R, Chong, ASC (2004). Preliminary study on the cryopreservation of tropical bagrid catfish (Mystusnemurus) spermatozoa; the effect of extender and cryoprotectant on the motility after short-term storage. Theriogenology62:25-34.

Nahiduzzaman M, Hassan MM, Khanam UH, Mamun SN. A, Hossain MAR, Tiersch TR (2011). Sperm cryopreservation of the critically endangered olive barb (Sarputi) Puntiussarana (Hamilton, 1822). Cryobiology, $62: 62-67$.

Rana KJ, McAndrew BJ (1989). The viability of cryopreserved Tilapia spermatozoa. Aquaculture, 76: 335-345.

Rao KG (1989). Cryopreservation of carp sperm.In: Das and Jhingran (eds.) Fish Genetics in India,
Today and Tomorrows Printers and Publishers, New Delhi. 193-198pp.

Sarder MRI, Rafiquzzaman SM, Islam MF (2009). Cryopreservation of spermatozoa of Mrigal, Cirrhinus cirrhosus with a view to minimize inbreeding and hybridization. J. Bangladesh Agril. Univ., 7(1) : 211-218.

Sarder MRI, Saha SK, Sarker MFM (2013). Cryopreservation of Sperm of An Indigenous Endangered Fish, Pabda (Ompok pabda, Hamilton-Buchanan, 1822). North American Journal of Aquaculture, 75:114-123.

Sarder MRI, Sarker MFM, Saha SK (2012). Cryopreservation of sperm of an indigenous endangered fish species Nandus nandus (Hamilton,1822) for ex-situ conservation. Cryobiology, 65:202-209.

Shafi M, Quddus MAA (1982). Bangladesher Matshya Sampad (in Bengeli), Bangla Academy, Dhaka, 1-444pp.

Shirohara J, Canto (Jr.) T, Rlmendras JMF (1982). A comparative study of various extenders for milk fish, Chanoschanos (Forssakal) sperm preservation. Aquaculture, 28: 339-346.

Talwar, PK, Jhingran AG (1991): Inland fishes of India and adjacent countries, vol. 2. A. A. Balkema, Rotterdam. 541p.

Tiersch TR (2000). Introduction, in T.R.Tiersch and P.M. Mazik, editors.Cryopreservation in Aquatic Species, World Aquaculture Society, Baton Rouge, LA, xix-xxvi pp.

Viveiros ATM, and So, N, Komen J (2000). Sperm cryopreservation of African Catfish, Clarias gariepinus: cryoprotectants, freezing rates and sperm:egg dilution ratio. Theriogenology, 54: 1395-1408.

Viveiros ATM, Lock EJH, Woelders, Komen J (2001). Influence of cooling rates and plunging temperatures in an interrupted slow-freezing procedure for semen of the African catfish, Clarias gariepinus. Cryobiology, 43: 276-287. 
Withler FC, Lim LC (1982). Preliminary observations of chilled and deep-frozen storage of grouper (Epinephelustauvina) sperm. Aquaculture, 27: 389-392.

Yang HL, Hazlewood RB, Walter, Tiersch TR (2006). Effect of osmotic immobilization on refrigerated storage and cryopreservation of sperm from a viviparous fish, the Green Swordtail Xiphophorus helleri. Cryobiology52:209-218.

Yang H, Carmichael C, Varga ZM, Tiersch TR. (2007). Development of a simplified and standardized protocol with potential for high-throughput for sperm cryopreservation in Zebrafish Danio rerio. Theriogenology, $68: 128-136$.

Zhang T, Rawson DM (2007). Studies of on cryopreservation of luc gene transfected bluegill sunfish fibroblast cell line. Cryoletter, 23: 191196. 
